Available online at GSC Online Press Directory

GSC Biological and Pharmaceutical Sciences

e-ISSN: 2581-3250, CODEN (USA): GBPSC2

Journal homepage: https://www.gsconlinepress.com/journals/gscbps

(RESEARCH ARTICLE)

\title{
Evaluation of in vivo and in vitro biological activities of Gardenia latifolia Ait leaf
}

\author{
Arif Md ${ }^{1}$, Kuddus Md. Ruhul ${ }^{2, *}$, Islam Md. Torequl ${ }^{1}$ and Ibrahim Mohammed ${ }^{1}$ \\ ${ }^{1}$ Department of Pharmacy, Southern University Bangladesh, Chittagong, Bangladesh. \\ 2 Department of Pharmaceutical Chemistry, Faculty of Pharmacy, University of Dhaka, Dhaka-1000, Bangladesh.
}

Publication history: Received on 30 May 2019; revised on 24 June 2019; accepted on 25 June 2019

Article DOI: https://doi.org/10.30574/gscbps.2019.7.3.0097

\begin{abstract}
Gardenia latifolia Ait. belonging to the family Rubiaceae is a flowering plant with high ethnomedicinal practices in Bangladesh. The current study evaluates analgesic, antipyretic, $\alpha$-amylase enzyme inhibition, membrane stabilizing, antioxidant effect and antimicrobial potentials of $G$. latifolia. The analgesic and antipyretic activity of ethanol extract of G. latifolia (EGL) leaves were evaluated by hot plate reaction model and brewers' yeast-induced hyperthermia model in mice, respectively. The $\alpha$-amylase inhibiting activity, membrane stabilizing activity, antioxidant activity and antimicrobial activity of EGL along with its hexane (HSGL) and chloroform (CSGL) soluble fractions were measured employing the starch-iodine method, hypotonic induced hemolysis assay, DPPH free radical scavenging assay and minimum inhibitory concentration (MIC) determination method, respectively. Here, EGL exhibited dose-dependent pain relieving activity in experimental mice. EGL also significantly $(\mathrm{p}<0.05)$ reduced the yeast-induced hyperthermia in mice over the experimental period. During the $\alpha$-amylase enzyme inhibition assay, the EGL at dose of $500 \mu \mathrm{g} / \mathrm{mL}$ showed maximum $\alpha$-amylase inhibitory activity (65.95\%). In membrane stabilizing assay, EGl, HSGL and CSGL were found to be effective for stabilizing erythrocyte membrane in hypotonic solution. During antioxidant assays, doseresponse curve of DPPH radical scavenging activity of the different soluble fractions of G. latifolia was obtained. Besides, these plant samples also displayed substantial antimicrobial activity against test microorganisms with MIC value ranged from 15.62 to $250 \mu \mathrm{g} / \mathrm{mL}$. In summary, the plant G. latifolila possesses a significant biological activity which validates its use in Bangladesh folk medicinal practices.
\end{abstract}

Keywords: Gardenia latifolia; Analgesic; Antipyretic; $\alpha$-amylase; Membrane stabilizing; Antioxidant; Antimicrobial

\section{Introduction}

Medicinal plants play an important role in the lives of rural people' particularly in remote area of developing countries. Nearly $80 \%$ people living in developing countries still depend on plant-based traditional medicine for their primary health care $[1,2]$. Based on potent biological actions, natural product chemists have been trying hard to isolate and identify bioactive leads from plant sources [3].

Gardenia latifolia Ait. is a small deciduous tree or large shrub growing up to $3 \mathrm{~m}$ tall. In Bangladesh the plant is widely distributed in Chittagong Hill Tracts and Cox's Bazar. G. latifolia is an important medicinal plant whose different parts are reported to use traditionally in treatment of a wide range of human diseases such as stomach pain, fevers, skin diseases, snake bite, inflammatory pain, caries, hemorrhage and ephemeral fever in live stocks [4]. Due to its broad spectrum healing potential, this medicinal tree can serve as a promising research target for various scientific studies. Bark of this plant contains saponins which may find use in asthma due to their inhibitory effect on histamine production. Phytochemical analysis led to isolation of hederagenin, D-mannitol, sitosterol and siaresinolic, episiaresinolic, oleanolic and spinosic acid from the stem bark of G. latifolia [5, 6].

\footnotetext{
${ }^{*}$ Corresponding author

E-mail address: ruhulkuddus@du.ac.bd
} 
As part of our continuing studies on medicinal plants of Bangladesh [7, 8] we evaluated the biological activities of ethanol crude extract of G. latifolia, EGL along with its solvent fractions (HSGL, CSGL) in order to find out the rationale for its folk uses and we, herein, report the results of our preliminary investigation.

\section{Material and methods}

\subsection{Collection, identification and extraction of plant material}

Leaves of Gardenia latifolia Ait. was collected from Tulaban area, Rangamati, Bangladesh and was identified by the taxonomist, Forest Research Institute, Bangladesh (BFRIH). After collection, leaves of G. latifolia were dried at temperature not exceeding 35 to $50^{\circ} \mathrm{C}$, and subjected to course grinding. The powdered material was subjected to hot extraction with ethanol by the Soxhlet apparatus [9]. The extraction was carried out for about $10 \mathrm{~h}$ and the extract was filtered through a cotton plug followed by Whatman filter paper no. 1. The extract was then concentrated by evaporating the solvent bellow $45^{\circ} \mathrm{C}$ temperature. After evaporation of the solvent, a gummy concentrate was obtained which was designated as ethanol crude extract of $G$. latifolia (EGL). The yield value of EGL was $16.71 \%$. About $5 \mathrm{~g}$ EGL was partitioned with $n$-hexane and chloroform to get $n$-hexane (HSGL) and chloroform (CSGL) soluble fractions, respectively which were then studied separately for the evaluation of biological activities.

\subsection{Drugs and reagent}

Ethanol, Tween 80, diclofenac-Na (Essential drugs company Ltd.), paracetamol (GSK pharmaceuticals Ltd.), acarbose (Pacific pharmaceuticals Ltd.), acetyl salicylic acid (Zenith pharmaceuticals Ltd.), ascorbic acid (AA).

\subsection{Experimental animal}

Swiss Albino mice (28-30 gm) of either sex aged 4-5 weeks were collected from the Animal Resources Branch of the International Centre for Diarrheal Diseases and Research, Bangladesh (icddr,b). They were housed in standard polypropylene cages and kept at room temperature $\left(24 \pm 2^{\circ} \mathrm{C}\right)$ and relative humidity $(60-70 \%)$ in a 12 hour light-dark cycle and are fed with icddr,b formulated diet and water ad libitum.

\subsection{Evaluation of analgesic activity}

The analgesic activity of the ethanol crude extracts of G. latifolia (EGL) was determined by the hot plate test method [10] with slightly modification. Mice were divided into four groups (I-IV) consisting of three animals in each group. Mice of group I served as control were treated with distillled water (DW), group II with diclofenac sodium (9 mg/kg body weight) intraperitonially (positive control) while group III and IV were treated intraperitonially with EGL at a doses of 250 and $500 \mathrm{mg} / \mathrm{kg}$ body weight, respectively. The animals were individually placed on the hot plate maintained at $55 \pm 2^{\circ} \mathrm{C}, 15 \mathrm{~min}$ after their respective treatments. The response time (in sec) was noted as the time at which animals reacted to the pain stimulus either by paw licking or jump response, whichever appeared first (latency). Moreover, the number of times jumped and number of times the paw licked was noted as a pain stimulus for $2 \mathrm{~min}$. The cut off time for the reaction was $15 \mathrm{sec}$. The greater the latency period and the lesser the paw licking or jump response, the more is the positive activity by the test extract.

\subsection{Evaluation of the anti-pyretic activity}

Antipyretic activity of EGL was measured by the method described by Adams et al. [11] with slightly modification. Mice were divided into four groups (I-IV) consisting of three animals in each group. Mice of group I were treated with saline $(10 \mathrm{~mL} / \mathrm{kg}$ body weight) as negative control, group II with paracetamol $(9 \mathrm{mg} / \mathrm{kg}$ body weight) as standard drug while test groups (Group III-IV) were treated intraperitonially with EGL at a doses of 250 and $500 \mathrm{mg} / \mathrm{kg}$ body weight, respectively. Brewer's yeast suspension $(10 \mathrm{~mL} / \mathrm{kg})$ was administered by intra-peritoneal route to induce pyrexia in albino mice. The rectal temperature of each mouse was measured using a digital thermometer after $24 \mathrm{~h}$ after the injection. Only mice that showed an increase in temperature of at least $0.7^{\circ} \mathrm{C}$ were used for the experiment. Rectal temperature of mice was recorded periodically after 1,2 and $3 \mathrm{~h}$ of drug administration.

\subsection{Evaluation of $\alpha$-amylase inhibiting activity}

The $\alpha$-amylase inhibiting activity of EGL and its two solvent fractions HSGL, CSGL was measured employing the starch-iodine method [12] using acarbose (conc. $50 \mu \mathrm{g} / \mathrm{mL}$ ) as standard. For standard acarbose serial dilutions were carried out to obtain concentration range from 31.25 to $250 \mu \mathrm{g} / \mathrm{mL}$ and for EGL concentration range from 31.25 to $500 \mu \mathrm{g} / \mathrm{mL}$. \%Inhibition of enzyme activity was calculated by comparing to the control which did not have the extract/drug. 
$\%$ Inhibition of enzyme activity $=(A-C) /(B-C) \times 100$

Where, $\mathrm{A}=$ absorbance of the plant sample, $\mathrm{B}=$ absorbance of blank (no extract), and $\mathrm{C}=$ absorbance of control (no extract).

\subsection{In-vitro anti-inflammatory and membrane stabilization activity}

The membrane stabilization activity of EGL, HSGL and CSGL was conducted by the method described by Vadivu and Lakshmi et al. [13] using spectrophotometer. For this experiment, four clean centrifuges were taken for standard, two for control and four for each of the plant samples. The tubes were marked accordingly. The assay mixture in each tube contains $1 \mathrm{~mL}$ phosphate buffer (pH 7.4, $0.15 \mathrm{M}), 2 \mathrm{~mL}$ hypo-saline $(0.36 \%), 0.5 \mathrm{~mL}$ HRBC suspension (10\% v/v) with $0.5 \mathrm{~mL}$ of plant samples i.e., EGL, HSGL, CSGL and standard acetyl salicylic acid (ASA) of various concentrations and control (distilled water instead of hypo-saline) were incubated at $37{ }^{\circ} \mathrm{C}$ for 30 min and centrifuged respectively. Membrane stabilizing activity was calculated by measuring the absorbance of the hemoglobin content in the supernatant solution at $560 \mathrm{~nm}$. The percentage hemolysis by the control group was calculated by assuming the hemolysis produced as $100 \%$.

Percentage hemolysis $=[$ (optical density of test solution $) \div($ optical density of control $)] \times 100$.

Percentage inhibition $=100-[($ optical density of test solution $) \div($ optical density of control $) \times 100]$.

\subsection{Evaluation of antioxidant activity}

The stable DPPH was used for the determination of free radical scavenging activity [14]. The antioxidant activity (free radical scavenging activity) of EGL, HSGL and CSGL on the stable radical 1, 1- diphenyl-2-picrylhydrazyl (DPPH) was determined by the method developed by Brand- Williams et al. [15].

\subsection{Determination of minimum inhibitory concentration}

Minimum inhibitory concentrations (MICs) are defined as the lowest concentration of the antimicrobial agent that inhibits the microbial growth after $24 \mathrm{~h}$ of incubation. MIC of the EGL, HSGL and CSGL was determined by serial dilution technique $[16,17]$ in broth medium (Hi Media Laboratories, India) containing graded concentration of the plant sample inoculated with the test organisms (Table 5).

\section{Results and discussion}

As shown in Table 1, EGL exhibited dose-dependent central analgesic activity in mice. Intraperitoneal treatment of $500 \mathrm{mg} / \mathrm{kg}$ body weight EGL induced 38.47 times jumping and 6.67 times paw licking in mice with 12.45 sec latency period for jumping and $43.76 \mathrm{sec}$ latency period for paw licking, whereas EGL at $250 \mathrm{mg} / \mathrm{kg}$ body weight showed 47.0 times jumping, 9.0 times paw licking, 7.03 sec latency period for jumping and 17.18 sec latency period for paw licking. This results indicate that EGL produced significant $(\mathrm{p}<0.02 ; \mathrm{p}<0.05)$ analgesic activity compared to the standard diclofenac-Na at a dose of $9 \mathrm{mg} / \mathrm{kg}$ body weight.

Table 1 Analgesic activity of EGL in mice

\begin{tabular}{llllll}
\hline & & & & \multicolumn{2}{c}{ Latency period (Sec) } \\
\cline { 5 - 6 } Treatment & Dose & $\begin{array}{l}\text { No. of time } \\
\text { jumped }\end{array}$ & $\begin{array}{l}\text { No. of times } \\
\text { paw licked }\end{array}$ & Jumps & Licks \\
\hline DW & $10 \mathrm{ml} / \mathrm{kg}$ & $47.0 \pm 16.3$ & $6.0 \pm 2.83$ & $31.33 \pm 11.8$ & $19.67 \pm 8.1$ \\
Diclofenac-Na & $9 \mathrm{mg} / \mathrm{kg}$ & $35.67 \pm 2.83^{\mathrm{b}}$ & $4.67 \pm 0.7^{\mathrm{b}}$ & $4.33 \pm 2.1^{\mathrm{a}}$ & $11.10 \pm 6.8^{\mathrm{b}}$ \\
EGL & $500 \mathrm{mg} / \mathrm{kg}$ & $38.47 \pm 8.49^{\mathrm{b}}$ & $6.67 \pm 1.41^{\mathrm{b}}$ & $12.45 \pm 2.93^{\mathrm{b}}$ & $43.76 \pm 5.47^{\mathrm{a}}$ \\
& $250 \mathrm{mg} / \mathrm{kg}$ & $47.0 \pm 2.83^{\mathrm{b}}$ & $9.0 \pm 2.83^{\mathrm{b}}$ & $7.03 \pm 0.53^{\mathrm{a}}$ & $17.18 \pm 5.08^{\mathrm{b}}$ \\
\hline
\end{tabular}


Table 2 Antipyretic activity of EGL on Brewer's yeast-induced pyrexia in mice

\begin{tabular}{lcccc}
\hline \multirow{2}{*}{ Treatment } & \multirow{2}{*}{ Dose } & \multicolumn{3}{c}{ Change in rectal temperature $\left({ }^{\mathbf{0}} \mathbf{F}\right)$} \\
\cline { 3 - 5 } & & $\mathbf{1 ~ h}$ & $\mathbf{2 ~ h}$ & $\mathbf{3} \mathbf{~ h}$ \\
\hline Normal saline & $10 \mathrm{ml} / \mathrm{kg}$ & $0.57 \pm 0.15$ & $0.27 \pm 0.10$ & $0.13 \pm 0.03$ \\
Paracetamol & $150 \mathrm{mg} / \mathrm{kg}$ & $1.33 \pm 0.16^{\mathrm{b}}$ & $2.1 \pm 0.10^{\mathrm{b}}$ & $2.57 \pm 0.30^{\mathrm{b}}$ \\
EGL & $250 \mathrm{mg} / \mathrm{kg}$ & $0.84 \pm 0.08^{\mathrm{b}}$ & $1.45 \pm 0.08^{\mathrm{b}}$ & $1.81 \pm 0.08^{\mathrm{a}}$ \\
& $500 \mathrm{mg} / \mathrm{kg}$ & $1.10 \pm 0.14^{\mathrm{b}}$ & $1.85 \pm 0.08^{\mathrm{b}}$ & $2.18 \pm 0.08^{\mathrm{a}}$ \\
\hline \multicolumn{4}{c}{} \\
& ${ }^{\mathrm{a}} \mathrm{p}<0.05 ;{ }^{\mathrm{b}} \mathrm{p}<0.01 ;$ values are expressed as mean \pm SEM.
\end{tabular}

Brewer's yeast-induced pyrexia in mice is a suitable method for the assessment of antipyretic activity of synthetic medications as well as plant products [18]. Subcutaneous injection of the yeast could evoke the production of prostaglandin and increases body temperature in mice at the various time intervals which were recorded rectally with the help of a digital thermometer [19]. Paracetamol a well-established antipyretic drug exerts its effect by the inhibition of prostaglandin production through the inhibition of cycloxygenase pathway [20]. As shown in table 2, EGL significantly $(\mathrm{p}<0.01, \mathrm{p}<0.05)$ reduced the yeast-induced hyperthermia in mice over the experimental period which was dose-dependent and comparable to standard drug paracetamol. The maximum antipyretic effect was observed for EGL at the $3^{\text {rd }} \mathrm{h}$ of observation. The findings of this study indicate that $G$. latifolia extractives could have potential of inhibition of prostaglandin synthesis as well as prominent antipyretic effect.

Table $3 \alpha$-amylase inhibitory activity of EGL, HSGL and CSGL

\begin{tabular}{|c|c|c|}
\hline Plant sample & Conc. $(\mu \mathrm{g} / \mathrm{mL})$ & $\begin{array}{l}\text { \% Inhibition of } \alpha \text { - } \\
\text { amylase activity }\end{array}$ \\
\hline \multirow{4}{*}{ EGL } & 500 & $65.95 \pm 0.03^{\mathrm{d}}$ \\
\hline & 250 & $51.72 \pm 0.04^{\mathrm{d}}$ \\
\hline & 125 & $46.34 \pm 0.01^{\mathrm{d}}$ \\
\hline & 62.5 & $42.11 \pm 0.02^{\mathrm{d}}$ \\
\hline \multirow{4}{*}{ HSGL } & 500 & $33.96 \pm 0.08^{c}$ \\
\hline & 250 & $31.99 \pm 0.06^{\mathrm{d}}$ \\
\hline & 125 & $27.54 \pm 0.03^{\mathrm{d}}$ \\
\hline & 62.5 & $26.99 \pm 0.04^{\mathrm{a}}$ \\
\hline \multirow{4}{*}{ CSGL } & 500 & $22.26 \pm 0.02^{\mathrm{b}}$ \\
\hline & 250 & $17.98 \pm 0.05^{b}$ \\
\hline & 125 & $12.44 \pm 0.03^{\mathrm{d}}$ \\
\hline & 62.5 & $9.84 \pm 0.01^{b}$ \\
\hline \multirow{4}{*}{ Acarbose } & 250 & $90.49 \pm 0.03$ \\
\hline & 125 & $87.12 \pm 0.02$ \\
\hline & 62.5 & $85.14 \pm 0.03$ \\
\hline & 31.25 & $74.77 \pm 0.04$ \\
\hline
\end{tabular}

In this study, EGL, HSGL and CSGL were investigated for their $\alpha$-amylase inhibition using a colorimetric method as mentioned earlier. The $\alpha$-amylase inhibitory potentials of the plant samples were compared with standard acarbose under our specific set of assay conditions. As shown in table 3, the entire sample had inhibitory action on $\alpha$-amylase enzyme which catalyzes the hydrolysis of starch into sugar. The consecutive doses of different soluble fractions of $G$. latifolia crude extract $(62.5-500 \mu \mathrm{g} / \mathrm{mL})$ and standard acarbose $(31.25-250 \mu \mathrm{g} / \mathrm{mL})$ produced a dose graded inhibition of $\alpha$-amylase activity (Table 3). Among the fractions, EGL at $500 \mu \mathrm{g} / \mathrm{mLdose}$ showed maximum $\alpha$-amylase inhibitory activity (65.95\%) compared to $90.49 \%$ inhibition exhibited by acarbose. These results indicated that these plant extract and its organic soluble fractions may contain bioactive phytoconstituents which are effective to reduce the rate of digestion and absorption of carbohydrates and thereby contribute for effective management of diabetes by 
decreasing the post-prandial hyperglycemia. Future studies will provide an insight for the molecular mechanisms by which these active compounds regulate glucose homeostasis.

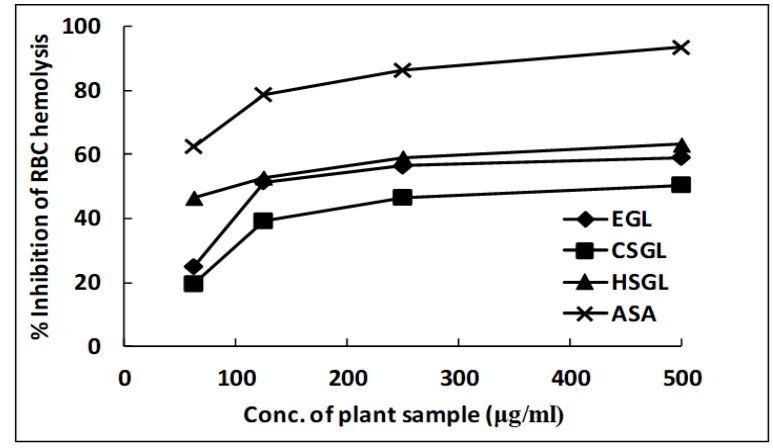

Figure 1 Membrane stabilizing assay of EGL, HSGL and CSGL on hypotonic induced hemolysis

As shown in figure 1, a dose-response relationship was observed during the membrane stabilizing assay and a comparative activity was presented by the standard acetyl salicylic acid. In this test EGL, HSGL and CSGL revealed prominent inhibition of RBC hemolysis in hypotonic solution. Among these three fractions, HSGL at the conc. of 500 $\mu \mathrm{g} / \mathrm{mL}$ showed highest level of membrane stabilizing activity (63.14\% inhibition of hemolysis), then followed by $59.04 \%$ and $50.64 \%$ inhibition exhibited by EGL and CSGL at the dose of $500 \mu \mathrm{g} / \mathrm{mL}$, respectively. Membrane stabilization assay of erythrocytes is a very popular tool to investigate the anti-inflammatory potential of the plant extracts. RBC membrane is considered alike cell membrane. The rupture of cell membrane due to exposure in hypotonic medium, heat, methyl salicylate, phenylhydrazine facilitates the release of lysosomal content (e.g. hydrolytic enzymes) which are associated with inflammation. The results (Figure 1) suggest that the plant extracts could have noticeable anti-inflammatory potential via membrane stabilization mechanism $[21,22]$.

A)

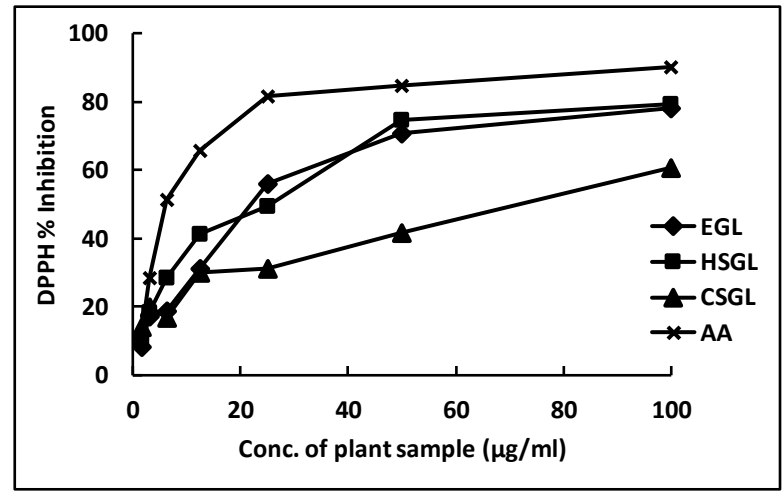

B)

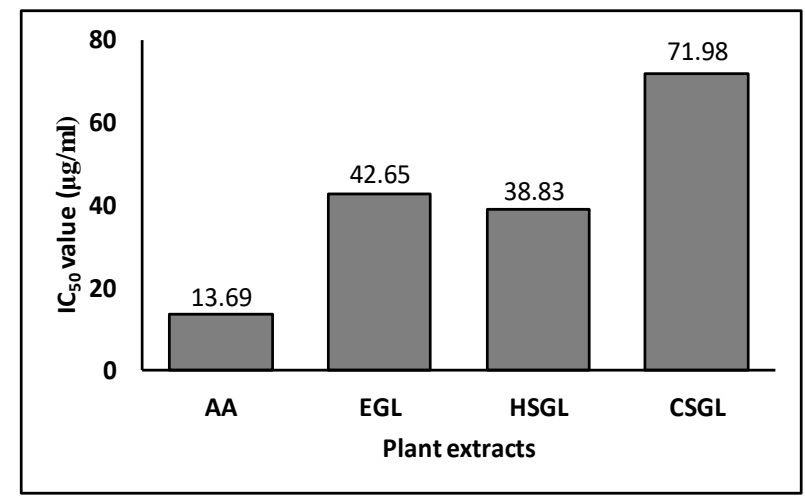

Figure 2 Antioxidant activity of EGL, HSGL and CSGL representing \% Inhibition of DPPH scavenging assay (A) and IC ${ }_{50}$ $(\mu \mathrm{g} / \mathrm{mL})$ values (B) of different organic soluble fractions of $G$. latifolia

The effect of antioxidant on DPPH is believed to be due to their hydrogen-donating ability [23]. The DPPH assay measures the antioxidant activity of water soluble phenolics [24]. Figure 2A shows the dose-response curve of DPPH radical scavenging activity of the different soluble fractions of $G$. latifolia leaves compared with standard ascorbic acid. It was observed that the HSGL had the highest activity, followed by EGL and CSGL, respectively. At the concentration of $0.1 \mathrm{mg} / \mathrm{mL}$, the scavenging activity of HSGL reached 79.29\% followed by EGL (78.41\%) and CSGL fraction (60.72\%), respectively whereas at the same concentration the standard ascorbic acid was $90.38 \%$ (Figure $2 \mathrm{~A}$ ). As shown in Figure 2B, the IC 50 of EGL, CSGL and HSGL was $42.65,38.83$ and $71.98 \mu \mathrm{g} / \mathrm{mL}$, respectively. The IC 50 of standard ascorbic acid was $13.69 \mu \mathrm{g} / \mathrm{mL}$. The lower the IC $\mathrm{C}_{50}$ value of a compound, the higher its radical scavenging activity [25]. The results obtained in this study suggest that all the soluble fractions of $G$. latifolia plant extract possess the strongest ability to scavenge DPPH radical. Due to their potential DPPH radical scavenging abilities, G. latifolia plant could serve as free radical scavengers, acting possibly as primary antioxidants. 
Table 5 Minimum inhibitory concentration (MICs) of EGL, HSGL and CSGL against test microorganisms

\begin{tabular}{lccc}
\hline \multirow{2}{*}{ Test microorganisms } & \multicolumn{3}{c}{ MICs ( $\mathbf{M g} / \mathbf{m L})$} \\
\cline { 2 - 4 } & EGL & HSGL & CSGL \\
\hline Bacteria & - & - & 31.25 \\
Bacillus cereus & - & - & 31.25 \\
B. megaterium & - & - & 31.25 \\
B. subtilis & - & - & 31.25 \\
Escherichia coli & - & 250 & 31.25 \\
Pseudomonas aeruginosa & 62.5 & 250 & 125 \\
Salmonella typhi & - & 250 & 31.25 \\
Staphylococcus aureus & - & 250 & 31.25 \\
Shigella dysenteriae & 62.5 & - & 62.5 \\
Sh. sonnei & 62.5 & - & 31.25 \\
Vibrio cholera & & & \\
Fungi & 62.5 & - & - \\
Aspergillus niger & 125 & 15.62 & 15.62 \\
Blastomyces dermatitidis & 125 & - & - \\
Candida albicans & - & - & 15.62 \\
Cryptococcus neoformans & & & \\
\hline
\end{tabular}

Table 5 shows the antimicrobial activity of EGL and its soluble fractions HSGL, CGL were evaluated through the determination of MIC values against Gram-positive and Gram-negative bacteria and fungi. The MIC concentrations ranged from 15.62 to $250 \mu \mathrm{g} / \mathrm{mL}$. The very high MIC values indicate only a very limited antibacterial efficacy. Of all the fractions, CSGL at the dose of $31.25 \mu \mathrm{g} / \mathrm{mL}$ showed the maximum activity against Bacillus cereus, $B$. megaterium, $B$. subtilis, S. aureus, P. aeruginosa, E. coli, Sh. dysenteriae and V. cholerae then followed by Sh. sonnei and S. typhi by 62.5 and $125 \mu \mathrm{g} / \mathrm{mL}$, respectively. Compared to bacteria, the CSGL showed better antifungal activity with MIC value of $15.625 \mu \mathrm{g} / \mathrm{mL}$ against both Blastomyces dermatitidis and Cryptococcus neoformans. The EGL also showed good activity with MIC value of $62.5 \mu \mathrm{g} / \mathrm{mL}$ against Sh. sonnei, S. typhi, V. cholera, A. niger, followed by MIC value of $125 \mu \mathrm{g} / \mathrm{mL}$ against Bl. dermatitides and C. albicans. In the present study, although bacterial strains were less sensitive (MIC value is $250 \mu \mathrm{g} / \mathrm{mL}$ ) to the HSGL but the growth of fungal strain Blastomyces dermatitidis was prominently inhibited by $15.62 \mu \mathrm{g} / \mathrm{mL}$ of HSGL.

\section{Conclusion}

G. latifolia is an important medicinal plant to the tribal people of Chittagong hill tracts area in Bangladesh. In this study, EGL exhibited significant $(\mathrm{p}<0.05)$ analgesic and antipyretic activity in test animals. Beside EGL, its fractions HSGL and CSGL were found to have prominent $\alpha$-amylase inhibitory activity. Similarly, all the plant samples have significant membrane stabilizing anti-inflammatory potential. In addition, HSGL was very capable to scavenge the free radicals which might be attributed to the high level of phenolic contents of the non-polar extractives. Moreover, antibacterial activity of the plant samples was confirmed in most test species. However, further bioassay guided investigations are required to identify the active principles and exact mechanism of action.

\section{Compliance with ethical standards}

\section{Acknowledgments}

The authors would like to acknowledge the Forest Research Institute, Bangladesh (BFRIH) (http://www.bfri.gov.bd/) for plant identification.

\section{Disclosure of conflict of interest}

The authors declare that they have no competing interests. 


\section{Statement of ethical approval}

The study was conducted following the guidelines approved by the Institution's ethical committee.

\section{References}

[1] Ridtitid W, Sae-Wong C, Reanmongkol W and Wongnawa M. (2008). Antinociceptive activity of the methanolic extract of Kaempferia galanga Linn. in experimental animals. Journal of Ethnopharmacology, 118(2), 225-230.

[2] Verma S and Singh SP. (2008). Current and future status of herbal medicine. Veterinary World, 1(11), 347-350.

[3] Dash PR. (2016). Phytochemical screening and pharmacological investigations on Hedychium coronarium. Anchor Academic Publishing, Hamburg, German, 1-72.

[4] Ansari F, Khare S, Dubey BK, Joshi A, Jain A and Dhakad S. (2019). Phytochemical analysis, antioxidant, antidiabetic and anti-inflammatory activity of bark of Gardenia latifolia. Journal of Drug Delivery and Therapeutics, 9(1), 141-145.

[5] Ray AS and Rahaman CH. (2008). Pharmacognostic, phytochemical and antioxidant studies of Gardenia latifolia Aiton: An ethnomedicinal tree plant. International Journal of Pharmacognosy and Phytochemical Research, 10(5), 216-228.

[6] Tamilselvi K, Ananad SP and Doss A. (2018). Evaluation of in-vitro antidiabetic activity of Gardenia Latifolia Ait. International Journal of Health Sciences and Research, 8(8), 226-230.

[7] Ibrahim M, Kuddus MR, Hossain MA and Rashid MA. (2017). Preliminary phytochemical screenings and pharmacological activities of three medicinal plants of Bangladesh. The Dhaka University Journal of Pharmaceutical Sciences, 16(2), 251-254.

[8] Moniruzzaman M, Kuddus MR, Chowdhury AMS and Rashid MA. (2019). Antioxidant, antimicrobial, antidiarrheal and analgesic activities of Diospyros malabarica (Desr.) Kostel. Bangladesh Pharmaceutical Journal, 22(1), 27-33.

[9] Redfern J, Kinninmonth M, Burdass D and Verran J. (2014). Using Soxhlet ethanol extraction to produce and test plant material (Essential Oils) for their antimicrobial properties. Journal of Microbiology \& Biology Education, 15(1), 45-46.

[10] Eddy NB and Leimbach D. (1953). Synthetic analgesics. II. Dithienylbutenyl- and dithienylbutylamines. Journal of Pharmacology and Experimental Therapeutics ,107(3), 385-393.

[11] Adams SS, Hebborn P and Nicholson JS. (1968). Some aspects of pharmacology of ibufenac, a non-steroidal antiinflammatory agent. Journal of Pharmacy and Pharmacology, 20(4), 305-312.

[12] Komaki E, Yamaguchi S, Maru I, Kinoshita M, Kakeyi K, Ohta Y and Tsukada Y. (2003). Identification of anti- $\alpha-$ amylase components from olive leaf extracts. Food Science and Technology Research, 9(1), 35-39.

[13] Vadivu R and Lakshmi KS. (2008). In-vitro and in-vivo anti-inflammatory activity of leaves of Symplocos cochinchinensis (Lour) Moore ssp Laurina. Bangladesh Journal of Pharmacology, 3(2), 121-124.

[14] Chowdhury A, Alam MA, Rahman MS, Hassan MA and Rashid MA. (2010). Antioxidant, antimicrobial and cytotoxic activities of Corypha taliera Roxb. Latin American Journal of Pharmacology, 29(7), 1231-1234.

[15] Brand-Williams W, Cuvelier ME and Berset C. (1995). Use of free radical method to evaluate antioxidant activity. Food Science \& Technology, 28(1), 25-30.

[16] Aktar F, Kuddus MR, Faruque SO, Rumi F, Quadir MA and Rashid MA. (2011). Antioxidant, cytotoxic, membrane stabilizing and antimicrobial activities of bark and seed of Entada phaseoloides (L.) Merr.: A medicinal plant from Chittagong Hill Tracts. Journal of Pharmacy and Nutrition Science, 1(2), 171-176.

[17] Tania KN, Islam MT, Ibrahim M, Kuddus MR and Rashid MA. (2012). Pharmacological and phytochemical screenings of ethanol extract of Sterculia villosa Roxb. Journal of Biomedical and Pharmaceutical Research, 2(1), 09-14.

[18] Naveed M, Saeed M and Khan H. (2012). Antipyretic, analgesic and anti-inflammatory activity of Viola betonicifolia whole plant. BMC Complementary and Alternative Medicine, 12, 59.

[19] Moltz H. (1993). Fever: causes and consequences. Neuroscience \& Biobehavioral Reviews, 17(3), 237-269. 
[20] Rawlins M and Postgrad R. (1973). Mechanism of salicylate-induced antipyresis. In: Pharmacology Thermoregulatory Proceeding Satellite Symposium, 311-324.

[21] Chaity FR, Khatun M and Rahman MS. (2016). In vitro membrane stabilizing, thrombolytic and antioxidant potentials of Drynaria quercifolia L., a remedial plant of the Garo tribal people of Bangladesh. BMC Complementary and Alternative Medicine, 16, 184.

[22] Saleem TM, Azeem AK, Dilip C, Sankar C, Prasanth NV and Duraisami R. (2011). Anti-inflammatory activity of the leaf extacts of Gendarussa vulgaris Nees. Asian Pacific Journal of Tropical Biomedicine, 1(2), 147-149.

[23] Ashafa AOT, Grierson DS and Afolayan AJ. (2010). In vitro antioxidant activity of extracts from the leaves of Felicia muricata Thunb. an underutilized medicinal plant in the Eastern Cape Province, South Africa. African Journal of Traditional, Complementary and Alternative Medicines, 7(4), 296-302.

[24] Chun SS, Vattem DA, Lin YT and Shetty K. (2005). Phenolic antioxidants from Clonal oregano (Origanum vulgare) with antimicrobial activity against Helicobacter pyroli. Process Biochemistry, 40(2), 809-816.

[25] Maisuthisakul P, Suttajit M and Pongsawatmanit R. (2007). Assessment of phenolic content and free radicalscavenging capacity of some Thai indigenous plants. Food Chemistry, 100(4), 1409-1418.

\section{How to cite this article}

Arif M, Kuddus MR, Islam MT and Ibrahim M. (2019). Evaluation of in vivo and in vitro biological activities of Gardenia latifolia Ait leaf. GSC Biological and Pharmaceutical Sciences, 7(3), 116-123. 